\title{
PHENOLIC CONSTITUENTS AND THE BIOLOGICAL ACTIVITY OF MENTHA LONGIFOLIA BY
}

Mohammed Hosny, Ehab A. Ragab, Mohammed F. Abd El-wahab and Hamdoon A. Mohammed FROM

Pharmacognosy Department, Faculty of Pharmacy, Al-Azhar University, Cairo, Egypt

\begin{abstract}
Phytochemical investigation of the constituents in acetone extract of the aerial parts of Mentha longifolia Linn. Hudson resulted in the isolation of five phenolic components. They were identified as rosmarinic acid [1], 4, 10-dihydroxy-3, 9-dimethoxy-pterocarpan (Melilotocarpan D) [2], Apigenin-4-methoxy-7- $O$-glucoside (Tilianin) [3], quercetin-3- $O$ - $\alpha$-L-rhamnopyranosyl$(1 \rightarrow 6)$ - $\beta$-D-glucopyranoside (Rutin) [4] and $p$-methoxy benzoic acid ( $p$-anisic acid) [5]. Their structures have been identified by their MS and NMR spectral data and confirmed by comparison with reference values. Compounds [2-5] were isolated from the genus Mentha for the first time, and compound [1] was isolated from $M$. longifolia for the first time. The cytotoxic, antioxidant and antimicrobial activities of the acetone extract were evaluated.
\end{abstract}

\section{INTRODUCTION}

Lamiaceae is an important plant family that has been investigated for its medicinal properties due to its large amounts of phenolic acids and flavonoids. One of the most important genus in the Lamiaceae family is Mentha which includes more than 25 species and many varieties (Bhat et al., 2002). Species of Mentha are widespread in the world and can be found in damp or wet places through temperate and sub temperate regions of the world (Gulluce et al., 2007; Voirin et al., 1999). Mentha species has been used in folk medicine for the treatment of headache, common cold, cough, sinusitis, bronchitis, fever, rheumatism, menstrual disorders and other different diseases, especially those connected with gastrointestinal symptoms such as nausea, vomiting, flatulence, anorexia, indigestion, gastritis, ulcerative colitis, intestinal colic and liver complaints due to its variety of biological properties, such as antiallergenic, antimicrobial, anti-inflammatory, antispasmodic, antiemetic, anticatharrhal, antioxidant, gastrointestinal protective, hepatoprotective, carminative, diaphoretic, analgesic and emmenagogue activities (Gulluce et al., 2007; Voirin et al., 1999). It is also used in the pharmaceutical, tobacco and cosmetology and as a condiment in various foods such as beverages, chewing gums, candies and cakes to give taste and odor (Areias et al., 2001; Asekun et al., 2007). Mentha longifolia Linn. Hudson is an erect aromatic perennial herb belonging to the family Laminaceae and is known as Horse mint or wild mint (Okoh and Afolayan, 2011). It is widespread throughout the Mediterranean, Central and Northern Europe, Asia Minor and Africa. Mentha longifolia which was a material of the present study produces a variety of constituents such as terpenes, essential oils, phenolic acids, flavonoids and flavonoid glycosides (Eli et al., 2012; Baris et al., 2001). Antioxidant, antibacterial, antiprotozoal (Al-Ali et al., 2013; Khan et al., 2011; Raj, et al., 2010) and hepatoprotective (Mimica-Dukić et al., 1999) activities of total phenolics and different extracts of Mentha longifolia have been investigated. We report here, the isolation and identification of five phenolic compounds [1-5] from the 
acetone extract of the aerial parts of Mentha longifolia, in addition to the determination of the cytotoxic, antioxidant and antimicrobial activities of the acetone extract.

\section{EXPERIMENTAL SECTION}

General experimental procedures. UV spectra were determined with a Hitachi 340 spectrophotometer. IR spectra were carried out on a Nicolet 205 FT IR spectrometer connected to a Hewlett-Packard Color Pro. Plotter. ESIMS were measured on a TSQ Quantum (Thermo Electron Corporation) instrument. The ${ }^{1} \mathrm{H}$ - and ${ }^{13} \mathrm{C}$ NMR measurements were obtained with a Varian Mercury $400 \mathrm{MHz}$ spectrometer at $400\left({ }^{1} \mathrm{H}\right)$ and $100 \mathrm{MHz}\left({ }^{13} \mathrm{C}\right)$ in $C_{3} O D$ or $C C_{C l}$ or DMSO- $d_{6}$ solution, and chemical shifts were expressed in $\delta(\mathrm{ppm})$ with reference to TMS, and coupling constant $(J)$ in Hertz. ${ }^{13} \mathrm{C}$ multiplicities were determined by the DEPT pulse sequence $\left(135^{\circ}\right)$. HMBC and HSQC NMR experiments were carried out using a Bruker DRX-400 high field NMR spectrometers. All 1D and 2D spectra were obtained using the standard Bruker software. Si gel (Si gel 60, Merck) and Sephadex LH-20 (Pharmacia) were used for open column chromatography. TLC was carried out on precoated silica gel $60 \mathrm{~F}_{254}$ (Merck) plates. Developed chromatograms were visualized by spraying with $1 \%$ vanillin- $\mathrm{H}_{2} \mathrm{SO}_{4}$, followed by heating at 100 ${ }^{0} \mathrm{C}$ for $5 \mathrm{~min}$.

\section{Plant material}

The aerial parts of Mentha longifolia were collected from Kafr Tabbloha, Al-Mnofeiah governorate, Egypt, in March, 2011, and were kindly identified by Dr. Nahaid El-Asinay, Professor of PlantTaxonomy, Faculty of Science, Cairo University, Egypt. A voucher specimen has been deposited in the Pharmacognosy Department, Faculty of Pharmacy, Al-Azhar University, Cairo, Egypt.

\section{Extraction and isolation}

The powder of air dried aerial parts of Mentha longifolia $(2 \mathrm{Kg})$ were subjected to exhaustive extraction with acetone ( $7 \mathrm{~L}$ x 3 ). The combined acetone extracts were concentrated under reduced pressure to yield a viscous extract $(80 \mathrm{~g})$. A part of the acetone extract $(10 \mathrm{~g})$ was applied to $\mathrm{Si}$ gel column and eluted with $n$-hexane-ethyl acetate: 100:0-0:100 followed by chloroform-methanol: 100:0-70:30 and gives seven fractions of A (530 mg), B (360 mg), C (800 $\mathrm{mg}), \mathrm{D}(470 \mathrm{mg}), \mathrm{E}(950 \mathrm{mg}), \mathrm{F}(640 \mathrm{mg})$ and $\mathrm{G}(1.5 \mathrm{~g})$. Fraction E was subjected to Si gel column eluted with $\mathrm{CH}_{2} \mathrm{Cl}_{2}-\mathrm{MeOH}(100: 0 \rightarrow 95: 5)$ to give five sub-fractions of E-1 (85 mg), E-2 (110 mg), E-3 (160 mg), E-4 (140 mg) and E-5 (90 mg). Sub-fractions E-1 and E-2 were repeatedly purified by Sephadex LH-20 column (MeOH) to yield compound [5] (25 mg) and compound [2] (42 mg), respectively. Fraction $\mathrm{F}$ was applied to $\mathrm{Si}$ gel column eluted with $\mathrm{CH}_{2} \mathrm{Cl}_{2}-\mathrm{MeOH}(100: 0 \rightarrow 75: 25)$ to give two sub-fractions of $\mathrm{F}-1(200 \mathrm{mg})$ and $\mathrm{F}-2$ (150 mg). Sub-fraction F-1 was purified by Sephadex LH-20 column (MeOH) to afford compound [1] (40 $\mathrm{mg})$. Fraction $\mathrm{G}$ was subjected to $\mathrm{Si}$ gel column eluted with $\mathrm{CH}_{2} \mathrm{Cl}_{2}-\mathrm{MeOH}(100: 0 \rightarrow 70: 30)$ to give four sub-fractions of G-1 (100 mg), G-2 (400 mg), G-3 (450 mg) and G-4 (300 mg). Subfractions G-2 and G-3 were repeatedly purified by Sephadex LH-20 column (MeOH) to afford compound [3] (45 mg) and compound [4] (50 mg), respectively. 


\section{Rosmarinic acid [1]:}

A colorless amorphous solid; UV $\lambda_{\max }(\mathrm{MeOH}) \mathrm{nm}: 225,290,325 ; \mathrm{IR} v_{\max }(\mathrm{KBr}) \mathrm{Cm}^{-1}$ : 3410, 3200-2500, 1710, 1640, 1600, 1520; ${ }^{1} \mathrm{H}$ and ${ }^{13} \mathrm{C}$ NMR data, see Table 1; ESIMS $\mathrm{m} / z$ $[\mathrm{M}+\mathrm{H}]^{+}, 383[\mathrm{M}+\mathrm{Na}]^{+}, 721[2 \mathrm{M}+\mathrm{H}]^{+}, 1081[3 \mathrm{M}+\mathrm{H}]^{+}, 1441[4 \mathrm{M}+\mathrm{H}]^{+}$.

\section{Melilotocarpan D [2]:}

A colorless amorphous solid; UV $\lambda_{\max }(\mathrm{MeOH}) \mathrm{nm}: 226,317,330$; IR $v_{\max }(\mathrm{KBr}) \mathrm{Cm}^{-1}$ : 3400, 1630, 1610, 1595, 1555; ${ }^{1} \mathrm{H}$ and ${ }^{13} \mathrm{C}$ NMR data, see Table 2; ESIMS $m / z, 317[\mathrm{M}+\mathrm{H}]^{+}, 631$ $[2 \mathrm{M}-\mathrm{H}]^{-}, 655[2 \mathrm{M}+\mathrm{Na}]^{+}, 971[3 \mathrm{M}+\mathrm{Na}]^{+}, 299[\mathrm{M}-\mathrm{OH}]^{+}$.

\section{Apigenin-4'methoxy-7- $O$ - $\beta$-D-glucopyranoside (Tilianin) [3]:}

Yellow amorphous powder $[\mathrm{MeOH}]$; UV $\lambda_{\max }(\mathrm{MeOH}) \mathrm{nm}: 269,330, \lambda_{\max }(\mathrm{MeONa}) \mathrm{nm}$ : 268, 370, $\lambda_{\max }\left(\mathrm{AlCl}_{3}\right) \mathrm{nm}: 279,301,355, \lambda_{\max }\left(\mathrm{AlCl}_{3} / \mathrm{HCl}\right) \mathrm{nm}: 277,305,348 \lambda_{\max }(\mathrm{AcONa})$ $\mathrm{nm}: 275,345,385, \lambda_{\max }\left(\mathrm{AcONa} /\right.$ boric acid) nm: 269, 330; IR $v_{\max }(\mathrm{KBr}) \mathrm{Cm}^{-1}: 3350(\mathrm{OH}), 1660$ (CO), $2930\left(\mathrm{OCH}_{3}\right), 1615,1585,1500\left(\mathrm{C}=\mathrm{C}\right.$ aromatic). ${ }^{1} \mathrm{H}$ NMR (DMSO- $\left.d_{6}, 400 \mathrm{MHz}\right)$ aglycon $\delta 12.99$ (1H, brs, OH-5), 8.04 (2H, d, $J=8.4$ Hz, H-2`, H-6 '), 7.11 (2H, d, J=8.4 Hz, H-3', H-5 ), $6.93\left(1 \mathrm{H}\right.$, brs, H-6), $6.84(1 \mathrm{H}, \mathrm{s}, \mathrm{H}-3), 6.45(1 \mathrm{H}, \mathrm{brs}, \mathrm{H}-8), 3.82\left(3 \mathrm{H}, \mathrm{s}, \mathrm{OCH}_{3}\right)$; sugar moiety $\delta$ $5.07\left(1 \mathrm{H}, \mathrm{d}, J=7.2 \mathrm{~Hz}, \mathrm{H}-1^{\prime \prime}\right), 3.71\left(1 \mathrm{H}, \mathrm{d}, J=11.2 \mathrm{~Hz}, \mathrm{H}-6 “{ }^{\prime}\right), 3.46$ (1H, m, H-6 `b), $3.44(1 \mathrm{H}$, m, H-5 '), 3.28 (1H, t, J=8.4 Hz, H-3“), $3.26\left(1 \mathrm{H}, \mathrm{m}, \mathrm{H}-2^{\prime \prime}\right), 3.15\left(1 \mathrm{H}, \mathrm{m}, \mathrm{H}-4{ }^{\prime \prime}\right) ;{ }^{13} \mathrm{C}$ NMR $\left(\mathrm{DMSO}-d_{6}, 400 \mathrm{MHz}\right)$ aglycon $\delta 182.08$ (C, C-4), 163.87 (C, C-2), 162.80 (C, C-4) 162.50 (C, C-7), 161.50 (C, C-9), 157.01 (C, C-5), 128.47 (CH, C-2`, 6 ) 122.69 (C, C-1'), 114.65 (CH, C3`, 5), 105.43 (C, C-10), $103.79(\mathrm{CH}, \mathrm{C}-3), 99.60$ (CH, C-6), 94.95 (CH, C-8); sugar moiety $\delta$ $\left.99.93\left(\mathrm{CH}, \mathrm{C}-1{ }^{\prime \prime}\right), 77.21\left(\mathrm{CH}, \mathrm{C}-5^{\prime}\right), 76.43\left(\mathrm{CH}, \mathrm{C}-3{ }^{\prime}\right), 73.11(\mathrm{CH}, \mathrm{C}-2 “)^{\prime}\right), 69.55\left(\mathrm{CH}_{2}, \mathrm{C}-4{ }^{\prime}\right)$, $60.61\left(\mathrm{CH}_{2}, \mathrm{C}-6 “\right), 55.63\left(\mathrm{OCH}_{3}\right)$; ESIMS m/z $447[\mathrm{M}+\mathrm{H}]^{+}$.

\section{Rutin [4]:}

Yellow amorphous powder $[\mathrm{MeOH}]$; UV $\lambda_{\max }(\mathrm{MeOH}) \mathrm{nm}: 260,363, \lambda_{\max }(\mathrm{MeONa})$ $\mathrm{nm}: 274,315,412, \lambda_{\max }\left(\mathrm{AlCl}_{3}\right) \mathrm{nm}: 275,305,434, \lambda_{\max }\left(\mathrm{AlCl}_{3} / \mathrm{HCl}\right) \mathrm{nm}: 271,303,400, \lambda_{\max }$ (AcONa) nm: 275, 320, 392, $\lambda_{\max }$ (AcONa/boric acid) nm: 262, 385; IR $v_{\max }(\mathrm{KBr}) \mathrm{Cm}^{-1}: 3400$ $(\mathrm{OH}), 1645(\mathrm{CO}), 1610,1590\left(\mathrm{C}=\mathrm{C}\right.$ aromatic). ${ }^{1} \mathrm{H}$ NMR $\left(\mathrm{CD}_{3} O D, 400 \mathrm{MHz}\right) \delta 7.56(1 \mathrm{H}, \mathrm{d}$, $\left.\left.J=2.0 \mathrm{~Hz}, \mathrm{H}-2^{`}\right), 7.50(1 \mathrm{H}, \mathrm{dd}, J=8.4,2.0 \mathrm{~Hz}, \mathrm{H}-6)^{\prime}\right), 6.76\left(1 \mathrm{H}, \mathrm{d}, J=8.4 \mathrm{~Hz}, \mathrm{H}-5^{`}\right), 6.24(1 \mathrm{H}, \mathrm{d}$, $J=2.0 \mathrm{~Hz}, \mathrm{H}-8), 6.06$ (1H, d, J=2.0 Hz, H-6), 4.67 (1H, d, J=7.6 Hz, H-1“) 4.42 (1H, brs, H-

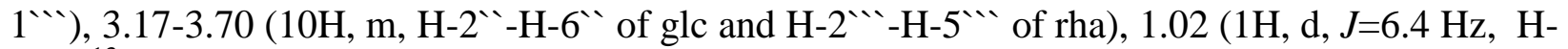
$6 “) ;{ }^{13} \mathrm{C}$ NMR $\left(\mathrm{CD}_{3} \mathrm{OD}, 100 \mathrm{MHz}\right) \delta 179.16(\mathrm{C}, \mathrm{C}-4), 165.89$ (C, C-7), 162.67 (C, C-5), 159.22 (C, C-2), 158.26 (C, C-9), 149.66 (C, C-4), 145.61 (C, C-3`), 135.56 (C, C-3), 123.56 (C, C-6 ), $122.96\left(\mathrm{CH}, \mathrm{C}-1^{`}\right), 117.68\left(\mathrm{CH}, \mathrm{C}-2^{`}\right), 115.98$ (CH, C-5 ) 105.44 (C, C-10), $104.74\left(\mathrm{CH}, \mathrm{C}-1^{\prime \prime}\right)$, 102.30 (CH, C-1“'), 99.93 (CH, C-6), 94.88 (CH, C-8), 78.02 (CH, C-3“), 76.98 (CH, C-5 “), $75.60\left(\mathrm{CH}, \mathrm{C}-2^{\prime \prime}\right), 73.83\left(\mathrm{CH}, \mathrm{C}-4^{\cdots}{ }^{\prime}\right), 72.13\left(\mathrm{CH}, \mathrm{C}-3^{\cdots}{ }^{\prime \prime}\right), 71.96\left(\mathrm{CH}, \mathrm{C}-2^{\cdots}{ }^{\prime \prime}\right), 71.25(\mathrm{CH}, \mathrm{C}-$ 4`), $69.61\left(\mathrm{CH}, \mathrm{C}-5^{\prime \prime}\right), 68.48\left(\mathrm{CH}_{2}, \mathrm{C}-6{ }^{\prime \prime}\right), 17.84\left(\mathrm{CH}_{3}, \mathrm{C}-6{ }^{\prime \prime}\right)$; ESIMS m/z $611[\mathrm{M}+\mathrm{H}]^{+}, 465$ $[\mathrm{M}-\text { rhamnose }+\mathrm{H}]^{+}, 303[\text { aglycon }+\mathrm{H}]^{+}$.

\section{p-methoxy benzoic acid [5]:}

White powder; UV $\lambda_{\max }(\mathrm{MeOH}) \mathrm{nm}: 215,270,320$; IR $v_{\max }(\mathrm{KBr}) \mathrm{Cm}^{-1}: 3400-2500$ $(\mathrm{OH}), 1680(\mathrm{CO}), 1600,1585,1517$ (aromatic $\mathrm{C}=\mathrm{C}), 1285(\mathrm{OMe}) ;{ }^{1} \mathrm{H} \mathrm{NMR}\left(\mathrm{CDCl}_{3}, 400 \mathrm{MHz}\right)$ $\delta 12.05(1 \mathrm{H}$, brs, OH), $7.33(2 \mathrm{H}, d, J=8.0 \mathrm{~Hz}, \mathrm{H}-2, \mathrm{H}-6), 6.92(2 \mathrm{H}, d, J=8.0 \mathrm{~Hz}, \mathrm{H}-3, \mathrm{H}-5), 3.81$ 
$\left(3 \mathrm{H}, \mathrm{s}, \mathrm{OCH}_{3}\right) ;{ }^{13} \mathrm{C} \mathrm{NMR}\left(\mathrm{CDCl}_{3}, 100 \mathrm{MHz}\right) \delta 168.64(\mathrm{C}, \mathrm{C}=\mathrm{O}), 163.19(\mathrm{C}, \mathrm{C}-4), 127.74(\mathrm{CH}$, C-2, C-6), 127.59 (C, C-1), 114.17 (CH, C-3, C-5), $55.37\left(\mathrm{CH}, \mathrm{OCH}_{3}\right) ;$ ESIMS m/z 151 [M-H]'.

\section{Acid hydrolysis of compounds [3] and [4].}

Five $\mathrm{mg}$ of each compound was separately refluxed with $2 \mathrm{M} \mathrm{HCl}$ in $\mathrm{MeOH}(5 \mathrm{ml})$ at 80 ${ }^{0} \mathrm{C}$ for $5 \mathrm{~h}$ in a water bath. The reaction mixture was evaporated, and the hydrolysate after dilution with $\mathrm{H}_{2} \mathrm{O}(10 \mathrm{ml})$ was extracted with $\mathrm{CHCl}_{3}(3 \mathrm{x} 10 \mathrm{ml})$. The $\mathrm{CHCl}_{3}$ extracts were evaporated to afford the aglycons, which were identified as 4 -methoxyapigenin and quercetin by comparison with authentic samples, respectively. The aqueous layer was neutralized with sodium carbonate and concentrated to $1 \mathrm{ml}$ under reduced pressure. The residue was compared with standard sugars by Si gel TLC $\left[\left(\mathrm{CHCl}_{3}-\mathrm{MeOH}-\mathrm{H}_{2} \mathrm{O}: 30: 12: 4\right), 9 \mathrm{ml}\right.$ of lower layer and $1 \mathrm{ml}$ of HOAc], which indicated the sugars to be glucose in [3] and glucose and rhamnose in [4].

\section{Cytotoxic assay}

Cytotoxic activity of acetone extract of Mentha longifolia was measured against Human colon carcinoma (HCT-116), human liver cancer (HepG-2) and Human breast cancer (MCF-7) cell lines as described by (Mosmann, 1983, Gangadevi and Muthumary, 2007). The cells were obtained from the American Type Culture Collection (ATCC, Rockville, MD). The cells were grown on RPMI-1640 medium supplemented with $10 \%$ inactivated fetal calf serum and $50 \mu \mathrm{g} / \mathrm{ml}$ gentamycin. The cells were maintained at $37^{\circ} \mathrm{C}$ in a humidified atmosphere with $5 \% \mathrm{CO}_{2}$ and were sub cultured two to three times a week. The results are presented in Table 3

\section{Antioxidant assay}

The free radical scavenging activity of the acetone extract of Mentha longifolia was measured by using 1,1-diphenyl-2-picryl-hydrazyl (DPPH) assay (Yen and Duh, 1994), at the Regional Center for Mycology and Biotechnology (RCMB) at Al-Azhar University. The results are recorded in Table 3 .

\section{Antimicrobial assay and determination of MIC}

The in vitro antimicrobial activity of acetone extract of Mentha longifolia was performed by agar cup plate diffusion method (Bauer, et al., 1966) at the Regional Center for Mycology and Biotechnology (RCMB) at Al-Azhar University. The antibacterial activity was carried out against three Gram-positive strains; Staphylococcus aureus (RCMB 010028), Bacillus subtilis (RCMB 010067) and Streptococcus pyogenes (RCMB 010015-13), three Gram-negative strains; Pseudomonas aeruginosa (RCMB 010043), Escherichia coli (RCMB 010052) and Klebsiella pneumonia (RCMB 0010093-9). The antifungal activity was carried out against three fungal strains; Aspergillus fumigates (RCMB 02568), Candida albicans (RCMB 05031) and Geotricum candidum (RCMB 05097). The microbial species are environmental and clinically pathogenic microorganisms obtained from Regional Center for Mycology and Biotechnology antimicrobial unit (RCMB), Al-Azhar University. The experiments were performed in triplicates and the mean diameter of zone of inhibition was measured in millimeter. The results are recorded in Table 4. The antibacterial and antifungal plant extract was then after evaluated to determine MIC value. The serial dilution technique by using $\mathrm{N}$-saline for diluting the plant extract was adopted and serially diluted plant extract tubes were incubated for $48 \mathrm{~h}$. The minimum dilution of plant 
extract that inhibited the growth of organisms was taken as MIC. The results are recorded in Table 4.

\section{RESULTS AND DISCUSSION}

In the present study we applied a series of separation and purification techniques, such as silica gel column chromatography, Sephadex LH-20 column chromatography, and recrystallization, yielding five compounds [1-5]. The structures of compounds were identified by comparisons of their spectral data (MS, ${ }^{1} \mathrm{H},{ }^{13} \mathrm{C}$-DEPT NMR, HMQC, HMBC) with the literature and direct comparisons with authentic standard substances. Compounds [2-5] were isolated for the first time from the genus Mentha.

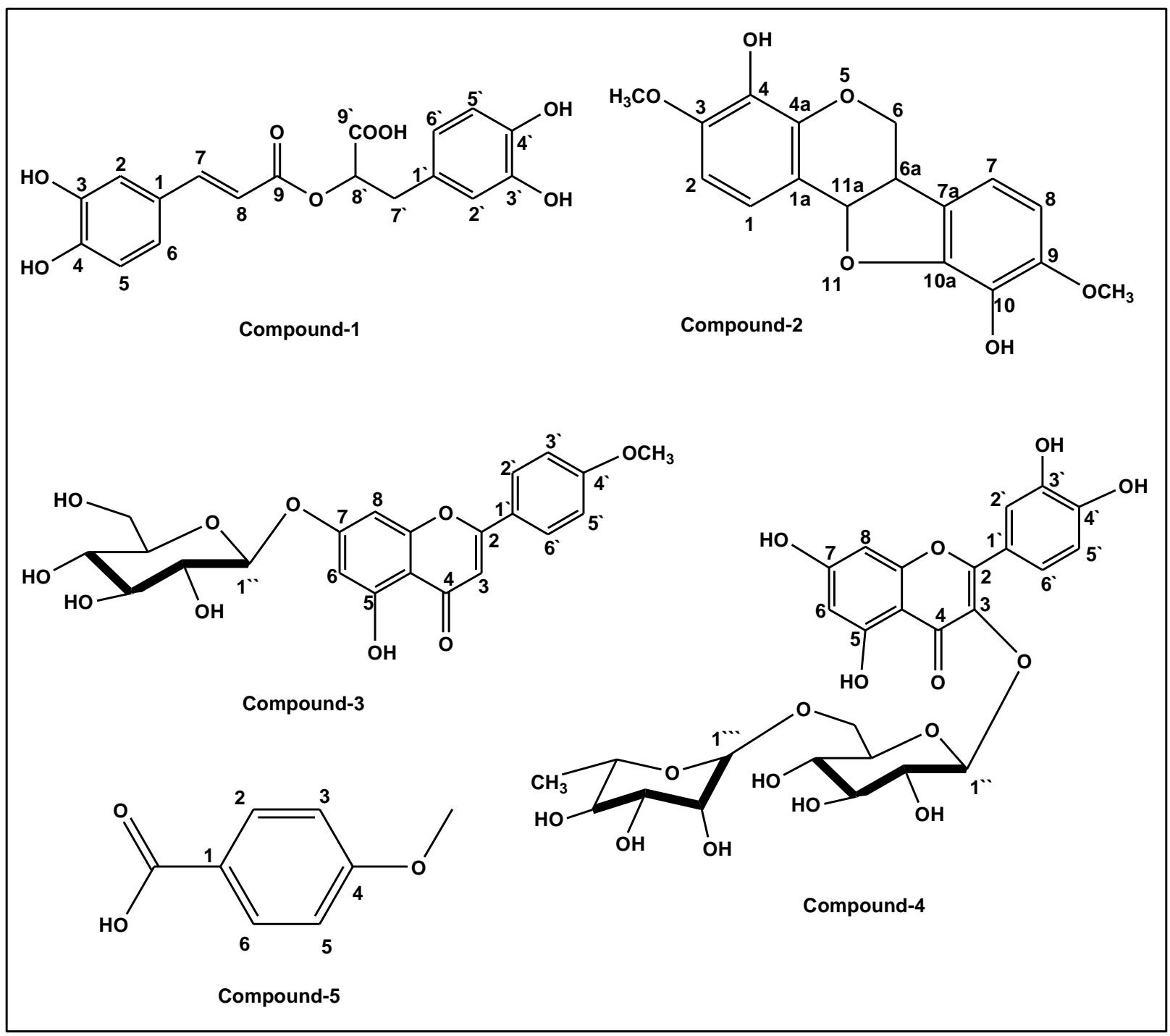

Compound [1] was isolated as a colorless amorphous solid and had a molecular formula $\mathrm{C}_{18} \mathrm{H}_{16} \mathrm{O}_{8}$, which was derived from its positive ESI MS at $\mathrm{m} / z 361[\mathrm{M}+\mathrm{H}]^{+}, 383[\mathrm{M}+\mathrm{Na}]^{+}$, and ${ }^{13}$ C-NMR spectrum (Table 1). Its UV spectrum showed absorption bands at 225, 290 and 325 
nm. The ${ }^{1} \mathrm{H}$ and ${ }^{13} \mathrm{C}$ NMR spectra indicated the presence of one $\beta$-(3,4-dihydroxyphenyl)-lactic acid moiety $[\delta 6.68(1 \mathrm{H}$, brs, H-2`), $6.62(1 \mathrm{H}, \mathrm{d}, J=8.1 \mathrm{~Hz}, \mathrm{H}-5), 6.50(1 \mathrm{H}, \mathrm{d}, J=7.5 \mathrm{~Hz}, \mathrm{H}-$ $6 `), 2.82(1 \mathrm{H}, \mathrm{t}, J=10.2 \mathrm{~Hz}, \mathrm{H}-7 ` \mathrm{a}), 3.06(1 \mathrm{H}, \mathrm{brd}, J=9.6 \mathrm{~Hz}, \mathrm{H}-7 ` \mathrm{~b}), 4.95$ (1H, brs, H-8`), and a $(E)$-caffeoyl unit $[\delta 7.06(1 \mathrm{H}$, brs, $\mathrm{H}-2), 6.76(1 \mathrm{H}, \mathrm{d}, J=8.0 \mathrm{~Hz}, \mathrm{H}-5), 6.95(1 \mathrm{H}, \mathrm{d}, J=8.1 \mathrm{~Hz}$, H-6), $7.38(1 \mathrm{H}, \mathrm{d}, J=16.1 \mathrm{~Hz}, \mathrm{H}-7), 6.18(1 \mathrm{H}, \mathrm{d}, J=16.3 \mathrm{~Hz}, \mathrm{H}-8)$ ], suggesting that [1] was a diphenolic acid. The $J$ value of the olefinic hydrogen of the caffeoyl unit was $16 \mathrm{~Hz}$, suggesting that the $(E)$-caffeoyl unit in [1]. This was further confirmed by the downfield chemical shift of caffeoyl C-9 (Tommasi et al., 1992). Consistent with the above ${ }^{1} \mathrm{H}-\mathrm{NMR}$ analysis, the ${ }^{13} \mathrm{C}-\mathrm{NMR}$ spectrum of compound [1] displayed signals for an aliphatic methylene at $\delta 36.72\left(\mathrm{C}-7^{\prime}\right)$, an oxygenated methine at $\delta 74.53\left(\mathrm{C}-8^{\prime}\right)$, two carbonyl carbons at $\delta 166.15$ (C-9) and 172.78 (C-9'), two olefinic carbons at $\delta 145.11(\mathrm{C}-7), 114.15(\mathrm{C}-8)$, and two sets of aromatic carbons at $\delta$ 148.63 (C-4), 145.77 (C-3), 144.98 (C-3'), 143.82 (C-4'), 128.79 (C-1'), 125.49 (C-1), 121.34 (C6), 119.92 (C-6'), 116.72 (C-2'), 115.97 (C-5), 115.50 (C-5'), 114.95 (C-2). These 1D NMR data, in combination with the observed 2D NMR (HMQC, HMBC) correlations, suggeted that compound [1] was a caffeic acid dimer. Thus, compound [1] was identified as rosmarinic acid by comparing the spectral data with those of reported data (Gohari et al., 2009; Satake et al., 1999).

Table 1: 1D and 2D NMR data of [1] (400 MHz for ${ }^{1} \mathrm{H}$ and $100 \mathrm{MHz}$ for ${ }^{13} \mathrm{C}$, DMSO- $\left.d_{6}\right)$

\begin{tabular}{|c|c|c|c|c|}
\hline Position & ${ }^{1} \mathrm{H}$ & ${ }^{13} \mathrm{C}$ & DEPT & HMBC \\
\hline 1 & - & 125.49 & $\mathrm{C}$ & - \\
\hline 2 & 7.06, brs & 114.95 & $\mathrm{CH}$ & C- 4,6 \\
\hline 3 & - & 145.77 & $\mathrm{C}$ & - \\
\hline 4 & - & 148.63 & $\mathrm{C}$ & - \\
\hline 5 & $6.76, \mathrm{~d}, 8.0$ & 115.97 & $\mathrm{CH}$ & C- $1,4,5$ \\
\hline 6 & $6.95, \mathrm{~d}, 8.1$ & 121.34 & $\mathrm{CH}$ & C- 2,4 \\
\hline 7 & $7.38, \mathrm{~d}, 16.1$ & 145.11 & $\mathrm{CH}$ & C- $2,6,9$ \\
\hline 8 & $6.18, d, 16.3$ & 114.15 & $\mathrm{CH}$ & C-1, 9 \\
\hline 9 & - & 166.15 & $\mathrm{C}$ & - \\
\hline 1 & - & 128.79 & $\mathrm{C}$ & - \\
\hline 2 & $6.68, \mathrm{brs}$ & 116.72 & $\mathrm{CH}$ & C-4, 6 \\
\hline 3 & - & 144.98 & $\mathrm{C}$ & - \\
\hline 4 & - & 143.82 & $\mathrm{C}$ & - \\
\hline 5 & $6.62, \mathrm{~d}, 8.1$ & 115.50 & $\mathrm{CH}$ & $\mathrm{C}-1,3$ \\
\hline 6 & $6.50, \mathrm{~d}, 7.5$ & 119.92 & $\mathrm{CH}$ & $\mathrm{C}-2,4$ \\
\hline 7 & $2.82, \mathrm{t}, 10.2$ & 36.72 & $\mathrm{CH}_{2}$ & \\
\hline 8 & 4.95 , brs & 74.53 & $\mathrm{CH}$ & \\
\hline 9 & - & 172.78 & $\mathrm{C}$ & - \\
\hline $\mathrm{OH}$ & 8.87, brs & & & \\
\hline
\end{tabular}

Compound [2] was isolated as a yellow amorphous powder and exhibited a pseudomolecular ion peak at $\mathrm{m} / \mathrm{z} 317[\mathrm{M}+\mathrm{H}]^{+}$in a positive ESIMS spectrum indicated a molecular formula $\mathrm{C}_{17} \mathrm{H}_{16} \mathrm{O}_{6}$. The ${ }^{1} \mathrm{H}$ NMR spectrum showed four aliphatic protons in a single spin system at $\delta 4.27(\mathrm{dd}, J=5.6,10.4 \mathrm{~Hz}), 3.62(\mathrm{~d}, J=6.1 \mathrm{~Hz}), 3.61(\mathrm{~d}, J=6.1 \mathrm{~Hz})$ and $5.55(\mathrm{~d}$, 
$J=5.8 \mathrm{~Hz}$ ), attributed to $\mathrm{CH}_{2}-6, \mathrm{H}-6 \mathrm{a}$ and $\mathrm{H}-11 \mathrm{a}$ of a pterocarpan skeleton, respectively (Table 2). The presence of a pterocarpan skeleton was supported by ${ }^{13} \mathrm{C}$ NMR and HMQC spectra, which showed the corresponding carbons at $\delta 66.5$ (C-6), 39.5 (C-6a) and 76.3 (C-11a). Furthermore, NMR spectroscopic data indicated the presence of two 1, 2, 3, 4-tetrasubstituted aromatic rings (both 1,2,3-trioxygenated according to ${ }^{13} \mathrm{C} N \mathrm{NMR}$ shift data), and two methoxy groups. The ${ }^{1} \mathrm{H}$ NMR spectrum showed two sets of ortho-coupled protons (AB spin systems), at $\delta 6.90(\mathrm{~d}, J=8.4 \mathrm{~Hz}, \mathrm{H}-1)$ and $6.68(\mathrm{~d}, J=8.5 \mathrm{~Hz}, \mathrm{H}-2)$ and $\delta 6.74(\mathrm{~d}, J=8.0 \mathrm{~Hz}, \mathrm{H}-7)$ and 6.47 (d, $J=8.1 \mathrm{~Hz}, \mathrm{H}-8) .{ }^{1} \mathrm{H}$ NMR signals corresponding to two phenolic $\mathrm{OH}$ groups were also observed. A literature search also suggested that [2] was likely to be a pterocarpene derivative (Ferreira et al., 1974; Miyase et al., 1999; He et al., 2006; Tanaka et al., 2002). The ESIMS and the UV data were also consistent with such a structure. More specifically, the units present and the molecular formula were consistent with a pterocarpene system substituted with two $\mathrm{OH}$ groups and two methoxy groups.

Table 2: 1D and 2D NMR data of [2] (400 MHz for ${ }^{1} \mathrm{H}$ and $100 \mathrm{MHz}$ for ${ }^{13} \mathrm{C}$, DMSO- $d_{6}$ )

\begin{tabular}{lllll}
\hline Position & ${ }^{1} \mathrm{H}$ & ${ }^{13} \mathrm{C}$ & DEPT & HMBC \\
\hline 1 & $6.90, \mathrm{~d}, 8.4$ & 120.44 & $\mathrm{CH}$ & $\mathrm{C}-2,3,4 \mathrm{a}, 11 \mathrm{a}$ \\
$1 \mathrm{a}$ & - & 114.36 & $\mathrm{C}$ & - \\
2 & $6.68, \mathrm{~d}, 8.5$ & 105.94 & $\mathrm{CH}$ & $\mathrm{C}-1 \mathrm{a}, 4$ \\
3 & - & 148.25 & $\mathrm{C}$ & - \\
4 & - & 134.61 & $\mathrm{C}$ & - \\
$4 \mathrm{a}$ & - & 144.42 & $\mathrm{C}$ & - \\
6 & $4.27, \mathrm{dd}, \quad 5.6, \quad 66.25$ & $\mathrm{CH}$ & $\mathrm{C}-4 \mathrm{a}, 7 \mathrm{a}, 11 \mathrm{a}$ \\
& 10.4 & & & $\mathrm{C}-4 \mathrm{a}, 7 \mathrm{a}, 11 \mathrm{a}$ \\
& $3.62, \mathrm{~d}, 6.1$ & & & \\
$6 \mathrm{a}$ & $3.61, \mathrm{~d}, 6.1$ & 39.70 & $\mathrm{CH}$ & $\mathrm{C}-6,7,10 \mathrm{a}$ \\
7 & $6.74, \mathrm{~d}, 8.0$ & 114.24 & $\mathrm{CH}$ & $\mathrm{C}-9,10,10 \mathrm{a}$ \\
$7 \mathrm{a}$ & - & 121.17 & $\mathrm{C}$ & - \\
8 & $6.47, \mathrm{~d}, 8.1$ & 104.83 & $\mathrm{CH}$ & $\mathrm{C}-9,10,7 \mathrm{a}, 10 \mathrm{a}$ \\
9 & - & 149.08 & $\mathrm{C}$ & - \\
10 & - & 131.03 & $\mathrm{C}$ & - \\
$10 \mathrm{a}$ & - & 147.25 & $\mathrm{C}$ & - \\
$11 \mathrm{a}$ & $5.55, \mathrm{~d}, 5.8$ & 78.18 & $\mathrm{CH}$ & $\mathrm{C}-1,6,1 \mathrm{a}, 4 \mathrm{a}, 7 \mathrm{a}$ \\
$\mathrm{OCH}_{3}-3$ & $3.76, \mathrm{~s}$ & 56.01 & OCH3 & $\mathrm{C}-3$ \\
$\mathrm{OCH}_{3}-9$ & $3.73, \mathrm{~s}$ & 56.21 & OCH3 & C-9 \\
$\mathrm{OH}^{2}$ & $8.49, \mathrm{brs}$ & - & - & \\
\hline
\end{tabular}

HMQC and HMBC NMR spectroscopic data were used to independently verify this conclusion, to determine the substitution pattern, and to locate the methoxy groups. The methoxy signal at $\delta$ 3.73 showed a correlation to an oxygenated aromatic carbon C-9 (149.08) which was also strongly correlated with the signals of aryl protons $\mathrm{H}-7$ and $\mathrm{H}-8$ at $\delta 6.74$ and 6.47 , respectively. These aryl protons showed additional strong correlations to $\mathrm{C}-10 \mathrm{a}$ and $\mathrm{C}-10$, respectively, both of which are also oxygenated aromatic carbons of the same 1,2,3-trioxygenated aromatic ring. $\mathrm{H}-7$ showed also a weak correlation to the (C-10), which is para to H-7. H-8 (ortho-coupled to $\mathrm{H}-7)$ also shows a weak correlation to $(\mathrm{C}-10 \mathrm{a})$, which is para to $\mathrm{H}-8$. The remaining carbon of 
this ring (C-7a) was located via its correlations with $\mathrm{H}-8$. C-7a was further linked to sp2 carbon $\mathrm{C}-6 \mathrm{a}$ on the basis of a strong correlation of H-6a to C-7. The $\left(\mathrm{CH}_{2}-6\right)$ was connected to C-6a by virtue of its strong correlation to $\mathrm{C}-7 \mathrm{a}$ and to two other oxygenated carbons, which must correspond to C-4a and C-11a. These data require C-6 to be connected to the second aromatic ring via an ether linkage which confirmed the presence of pyran ring. The signals for the second tetrasubstituted aromatic ring could be assigned on the basis of HMBC correlations of the methoxy signal at $\delta 3.76$ to an oxygenated aromatic carbon C-3 (148.25) which was also strongly correlated with the signals of aryl proton $\mathrm{H}-1$ at $\delta$ 6.90. This aryl proton (H-1) showed strong correlations to C-2, C-4a and C-11a. H-2 (ortho-coupled to H-1) also shows a strong correlations to $\mathrm{C}-4$ and $\mathrm{C}-1 \mathrm{a}$. The formula requires connection of $\mathrm{O}-11$ to $\mathrm{C}-11 \mathrm{a}$ to complete the structure of [2]. The absolute $R$ configuration of both chiral centres 6 a and 11a can be assigned on the basis of cis-diaxial relationship of their hydrogens $(J=6.1 \mathrm{~Hz})$ (Baruah et al., 1984). All the above evidence combined with HMQC and HMBC correlations confirmed the structure of [2] to be Melilotocarpan D (4, 10-dihydroxy, 3, 9-dimethoxy-terocarpan or 4, 10-dihydroxyhomoterocarpin, previously isolated from natural sources (Harborne, 1994).

Compound [3] was obtained as a pale yellow amorphous powder. Its molecular formula was deduced to be $\mathrm{C}_{22} \mathrm{H}_{22} \mathrm{O}_{10}$, from the molecular ion peak at $\mathrm{m} / \mathrm{z} 447[\mathrm{M}+\mathrm{H}]^{+}$in the ESIMS spectrum and from the ${ }^{13} \mathrm{C}$ NMR data. The UV spectrum of [3] showed two absorption bands at 269 and $330 \mathrm{~nm}$ which are typical for flavones and flavonols. The UV-shift reagents indicate that, 7- and 4 -hydroxyl groups are not free and the absence of $O$-dihydroxy groups (Markham, 1982). IR absorptions at $3350,1660,1615,1585$ and $1500 \mathrm{~cm}^{-1}$ indicated the presence of hydroxyl groups, carbonyl group and aromatic ring. The ${ }^{13} \mathrm{C}$ NMR spectrum gave 22 carbon signals and the DEPT spectrum confirmed that fourteen of these were protonated carbons. The DEPT spectrum further showed one methoxy, one methylene, twelve methine and eight quaternary carbons (including one carbonyl at $\delta$ 182.08) in agreement with the molecular formula. This indicated the presence of a flavonol glycoside. The nature and identity of the flavonol was evident from the ${ }^{1} \mathrm{H}$ NMR spectrum which showed the presence of an AA'BB' system of aromatic protons at $\delta 8.04\left(2 \mathrm{H}, \mathrm{d}, J=8.4 \mathrm{~Hz}, \mathrm{H}-2{ }^{\prime}, \mathrm{H}^{-} 6^{\prime}\right)$ and $\delta 7.11(2 \mathrm{H}, \mathrm{d}, J=8.4 \mathrm{~Hz}$, $\left.\mathrm{H}-3^{\prime}, \mathrm{H}-5^{\prime}\right)$ corresponding to a $p$-substituted ring $\mathrm{B}$, two signals at $\delta 6.93(1 \mathrm{H}$, brs, $\mathrm{H}-6)$ and 6.45 $(1 \mathrm{H}$, brs, $\mathrm{H}-8)$ corresponding to ring $\mathrm{A}$ and one signal at $\delta 6.84(1 \mathrm{H}, \mathrm{s})$ corresponding to ring $\mathrm{C}$ $\mathrm{H}-3$. The presence of a methoxy was evident from the sharp $3 \mathrm{H}$ signals at $\delta 3.82 \mathrm{ppm}$. A chelated $\mathrm{OH}$ group at $\mathrm{C}-5$ could be attributed to a lower field broad signal at $\delta 12.99$. The sugar moiety was established from the ${ }^{1} \mathrm{H}$ and ${ }^{13} \mathrm{C}$ NMR signals at $\delta_{\mathrm{H}} 5.07\left(1 \mathrm{H}, \mathrm{d}, J=7.2 \mathrm{~Hz}, \mathrm{H}-1^{\prime \prime}\right)$ and $\delta_{\mathrm{C}}$ 99.93, which are consistent with the presence of a glucose unit. Acid hydrolysis of [3] gives Dglucose as sugar component and 4-methoxyapigenin as the aglycon by comparison with authentic sample. The sugar was determined to be in the pyranose form from its ${ }^{13} \mathrm{C}$ NMR data. The $\beta$-anomeric configuration of glucose was defined from the chemical shift and ${ }^{3} J_{\mathrm{H} 1, \mathrm{H} 2}$ coupling constant (Gorin and Mazurek, 1975). The attachment of the glucose moiety to the C-7 position was deduced from the upfield shift of C-7 and the downfield shifts of the ortho-related carbons C-6 and C-8 and para-related carbon C-10 (Markham et al., 1978). Furthermore, the downfield shifts of C-4 and the upfield shifts of the ortho-related carbons C-3` and C-5 indicate that, C-4 is the site of methoxylation (Wagner et al., 1976). On the basis of the above evidences compound [3] was elucidated as apigenin-4-methoxy-7-O- $\beta$-glucoside (tilianin) and its spectroscopic data were in good agreement with the literature data (Malikova and Yuldashev, 2002). 
Compound [4] was obtained as yellow amorphous powder. The UV spectrum of [4] showed two absorption maxima at 260 and $363 \mathrm{~nm}$ which are typical for flavones and flavonols (Markham, 1982). The bathochromic shift of band I by about $49 \mathrm{~nm}$ after the addition of $\mathrm{NaOMe}$ indicates the presence of free 4 -hydroxyl group. The addition of $\mathrm{AlCl}_{3}$ showed bathochromic shift by $15 \mathrm{~nm}$ of band II and $71 \mathrm{~nm}$ of band I indicates the possibility of the presence of $\mathrm{B}$ ring $O$-dihydroxyl group at 3 and 4 and free 5-hydroxyl group. The addition of $\mathrm{HCl}$ to the $\mathrm{AlCl}_{3}$ spectrum of [4] resulted in the decrease of the bathochromic shift of band I by $34 \mathrm{~nm}$ which confirmed the presence of $O$-dihydroxyl group in B ring. The addition of NaOAc showed a bathochromic shift of band I by $29 \mathrm{~nm}$ indicative of the ionization of hydroxyl group located at position 4 while the shift of band II by $15 \mathrm{~nm}$ could be attributed to the ionization of hydroxyl group at position 7. Furthermore, the marked bathochromic shift of band I by $22 \mathrm{~nm}$ on the addition of a mixture of $\mathrm{NaOAc} / \mathrm{H}_{3} \mathrm{BO}_{3}$ indicates the presence of $O$-dihydroxy group at position 3 and 4 and/or 4 and 5 in B ring (Markham, 1982). The IR spectrum indicated the presence of hydroxyl groups, carbonyl group and aromatic ring from the absorption maxima at $3400,1645,1610,1590 \mathrm{~cm}^{-1}$. ESI-MS of [4] showed a peak at $\mathrm{m} / z 611$ for $[\mathrm{M}+\mathrm{H}]^{+}$ corresponding to the molecular formula $\mathrm{C}_{27} \mathrm{H}_{30} \mathrm{O}_{16}$. In the ${ }^{1} \mathrm{H}$ NMR spectrum of [4], two signals at $\delta 6.24(1 \mathrm{H}, \mathrm{d}, J=2.0 \mathrm{~Hz})$ and $6.06(1 \mathrm{H}, \mathrm{d}, J=2.0 \mathrm{~Hz})$, were assigned to $\mathrm{H}-8$ and $\mathrm{H}-6$ of the A ring, respectively. The ${ }^{1} \mathrm{H}$ NMR spectrum also exhibited a typical $\mathrm{ABX}$ system at $\delta 7.56(1 \mathrm{H}, \mathrm{d}$, $\left.\left.J=2.0 \mathrm{~Hz}, \mathrm{H}-2^{`}\right), 7.50(1 \mathrm{H}, \mathrm{dd}, J=8.4,2.0 \mathrm{~Hz}, \mathrm{H}-6)^{\prime}\right)$ and $6.76\left(1 \mathrm{H}, \mathrm{d}, J=8.4 \mathrm{~Hz}, \mathrm{H}-5^{\prime}\right)$ corresponding to three aromatic protons of $\mathrm{B}$ ring. These data indicated that the aglycon of [4] was a 3, 5, 7, 3 4 4 penta-oxygenated flavonol derivative which is in good agreement with quercetin. Two anomeric proton resonances were observed in the ${ }^{1} \mathrm{H}$ NMR spectrum of [4] at $\delta$ $4.67\left(1 \mathrm{H}, \mathrm{d}, J=7.6 \mathrm{~Hz}, \mathrm{H}-1^{\prime \prime}\right)$ and $4.42(1 \mathrm{H}$, brs, H-1 '“), indicated the presence of one $\beta$-Dglucose and one $\alpha$-L-rhamnose moieties in [4]. In addition the appearance of the strong sharp signal at $\delta 1.02\left(3 \mathrm{H}, \mathrm{d}, J=6.4 \mathrm{~Hz}, \mathrm{H}-6^{\prime \prime}\right)$ for the secondary methyl of rhamnose confirmed the rhamnose unit. The ${ }^{13} \mathrm{C}$ NMR spectrum of [4] also supported the structure assigned on the bases of comparison with those of rutin. It also revealed that sugar moiety consisted of one molecule of glucose and one molecule of rhamnose, based on the existence of two anomeric carbon signals at $\delta 104.74 \mathrm{ppm}\left(\mathrm{C}-1^{\prime \prime}\right)$ of glucose and $\delta 102.30 \mathrm{ppm}\left(\mathrm{C}-1^{\prime \prime}\right)$ of rhamnose and the signal at $\delta$ 17.84 ppm (C-6") of rhamnose. Acid hydrolysis of [4] gives D-glucose and L-rhamnose as sugar components and quercetin as the aglycon by comparison with authentic samples. The two sugars were determined to be in the pyranose forms from their ${ }^{13} \mathrm{C} N M R$ data. The $\beta$-anomeric configuration of glucose and the $\alpha$-anomeric configuration of rhamnose were defined from their chemical shifts and ${ }^{3} J_{\mathrm{H} 1, \mathrm{H} 2}$ coupling constants (Gorin and Mazurek, 1975). The site of rhamnose unit was established to be at C-6 of glucose from the observed downfield shift of C-6 of glucose $(\delta 68.48)$ and from the HMBC correlation observed between the anomeric proton of rhamnose and C-6 of glucose. Furthermore the fragment ion peak at $\mathrm{m} / \mathrm{z} 465[\mathrm{M} \text {-rhamnose }+\mathrm{H}]^{+}$, observed in the ESIMS spectrum indicated that the rhamnose unit is the terminal sugar. The attachment of the disaccharid moiety to C-3 was deduced from the long-range correlation between the anomeric proton of glucose (5.33) and C-3 (135.56) of the aglycon, as observed in the HMBC spectrum, which was also confirmed by the downfield shift of the ortho-related carbon C-2 ( $\delta 157.07$ ppm) (Ternai and Markham 1976; Agrawal, 1989; Markham, et al., 1978), with respect to quercetin. On the base of the above mentioned data compound [4] was distinguished as quercetin-3- $O$ - $\alpha$-L-rhamnopyranosyl- $(1 \rightarrow 6)-\beta$-D-glucopyranoside (rutin) and in good agreement with the reported literatures (Harborne, 1994; Markham et al., 1978; Wagner et al., 1976; Lee et al., 2004). 
Compound [5] was obtained as white powder. Its UV spectrum showed an absorption band at 215, 270 and $320 \mathrm{~nm}$. Its molecular formula was concluded to be $\mathrm{C}_{8} \mathrm{H}_{8} \mathrm{O}_{3}$ from the molecular ion peak at $m / z 151[\mathrm{M}-\mathrm{H}]^{-}$in the negative mode ESI-MS spectrum together with the data obtained from its ${ }^{13} \mathrm{C}$ NMR. The assignment of all protons and their corresponding carbons of [5] was confirmed by HMQC experiment. In the ${ }^{1} \mathrm{H}$ NMR spectrum of [5], the presence of an

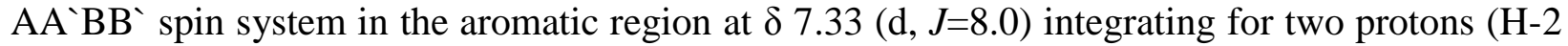
and $\mathrm{H}-6)$ and $\delta 6.92(\mathrm{~d}, J=8.0)$ integrating for two protons $(\mathrm{H}-3$ and $\mathrm{H}-5)$ indicating the presence of 1, 4-disubstituted benzene ring. A sharp singlet at $\delta 3.81$ indicates the presence a methoxyl group. In addition to signals for a carbonyl carbon at $\delta 168.64$, two pairs of equivalent nonoxygenated carbon methins at $\delta 127.74$ (C-2, C-6) and $\delta 114.17$ (C-3, C-5), one oxygenated quaternary carbon at $\delta 163.19(\mathrm{C}-4)$, one oxygenated methyl carbon at $\delta 55.37\left(\mathrm{OCH}_{3}\right)$ and one non-oxygenated quaternary carbon at $\delta 127.59(\mathrm{C}-1)$ in the ${ }^{13} \mathrm{C}$ and ${ }^{13} \mathrm{C}$-DEPT NMR spectra, confirming [5] to be $p$-methoxy benzoic acid and in good agreement with the reported literatures (Shabana et al., 2013).

\section{The cytotoxic activity}

As shown from Table 3, the acetone extract exhibited the highest cytotoxic activity against the HCT-16 cell line with value of $\mathrm{IC}_{50} 5.68 \mu \mathrm{g} / \mathrm{ml}$ followed by HepG2 cell line with value of $\mathrm{IC}_{50} 8.71 \mu \mathrm{g} / \mathrm{ml}$ and a week activity against the MCF-7 cell line with value of $\mathrm{IC}_{50}$ $35.7 \mu \mathrm{g} / \mathrm{ml}$.

\section{The antioxidant activity}

As expected the non-polar compounds present in the acetone extract had poor radical scavenging activities compared to the control (Table 3).

Table 3: Cytotoxic and antioxidant activities of acetone extract of Mentha longifolia

\begin{tabular}{|c|c|c|c|c|}
\hline \multirow{2}{*}{ Sample } & \multicolumn{3}{|c|}{ Cytotoxic activity $\left(\mathrm{IC}_{50} \mu \mathrm{g} / \mathrm{ml}\right)^{1}$} & \multirow{2}{*}{$\begin{array}{l}\text { Antioxidant } \\
\text { activity/(IC } \\
\mu \mathrm{go} / \mathrm{ml})^{2}\end{array}$} \\
\hline & НCТ-116 & HepG-2 & $\mathrm{MCF}-7$ & \\
\hline Acetone extract & 5.68 & 8.71 & 35.7 & 108.7 \\
\hline Ascorbic acid & - & - & - & 11.2 \\
\hline
\end{tabular}

\section{The antimicrobial activity}

The in vitro studies in this work showed that acetone extract inhibited the growth of all tested bacteria except $P$. aeruginos $a$ and observed good antifungal activity against all the fungal strains except $C$. albicans (Table 4). The highest inhibitory effect was observed against $B$. subtilis and $K$. pneumonia (zone of inhibition: $21.3 \mathrm{~mm}$ ) while the weakest activity was demonstrated against $S$. aureus (zone of inhibition: $19.8 \mathrm{~mm}$ ). The results are in accordance with the previous studies done on this aspect. In view of the results obtained by the agar diffusion method, the minimal inhibitory concentration MIC of acetone extract was determined by broth 
microdilution assay (Table 4). The highest MIC value $(3.9 \mu \mathrm{g} / \mathrm{ml})$ was observed against $S$. aureus, S. pyogenes and E. coli, while B. subtilis and $K$. pneumonia ranked next (MIC 1.95 $\mu \mathrm{g} / \mathrm{ml})$. Moreover, acetone extract observed good antifungal activity against the fungal strains i.e. A. fumigates and G. candidum (zone of inhibition range: 21.4-22.6 mm; MIC: 0.98-0.24 $\mu \mathrm{g} / \mathrm{ml})$. The standard drugs ampicillin and gentamycin were active against all reference bacteria (zone of inhibition range: $22.8-27.4 \mathrm{~mm}$ and 17.3-25.8 $\mathrm{mm}$; MIC range: $0.015-0.24 \mu \mathrm{g} / \mathrm{ml}$ and $0.03-15.63 \mu \mathrm{g} / \mathrm{ml}$, respectively). In addition, amphotericin B demonstrated good antifungal activity against all the fungal strains (zone of inhibition range: 19.8-28.7 mm; MIC range: 0.015$3.9 \mu \mathrm{g} / \mathrm{ml})$.

Table (4): Diameter of zone of inhibition (mm) and Minimum Inhibitory Concentration (MIC) of the acetone extract of Mentha longifolia

\begin{tabular}{lllll}
\hline \multirow{2}{*}{$\begin{array}{l}\text { Tested } \\
\text { microorganisms }\end{array}$} & \multicolumn{2}{l}{ Diameter of inhibition zone $(\mathbf{m m})$} & MIC $(\mu \mathrm{g} / \mathrm{ml})$ & \\
\cline { 2 - 5 } G + ve bacteria & & Standard & Extract & Standard \\
S. aureus & $19.8 \pm 0.58$ & $27.4 \pm 0.18$ & 3.9 & Ampicillin \\
B. subtilis & $21.3 \pm 0.22$ & $32.4 \pm 0.10$ & 1.95 & 0.03 \\
S. pyogenes & $20.6 \pm 0.58$ & $22.8 \pm 0.37$ & 3.9 & 0.015 \\
G - ve bacteria & & Gentamycin & & 0.24 \\
P. aeruginosa & $\mathrm{NA}$ & $17.3 \pm 0.15$ & $\mathrm{NA}$ & Gentamycin \\
E. coli & $19.9 \pm 0.58$ & $22.3 \pm 0.18$ & 3.9 & 15.63 \\
K. pneumonia & $21.3 \pm 0.44$ & $25.8 \pm 0.58$ & 1.95 & 0.49 \\
Fungi & & Amphotericin B & & 0.03 \\
A. fumigates & $21.4 \pm 0.58$ & $23.7 \pm 0.10$ & 0.98 & Amphotericin B \\
C. albicans & $\mathrm{NA}$ & $19.8 \pm 0.20$ & $\mathrm{NA}$ & 0.12 \\
G. candidum & $22.6 \pm 0.44$ & $28.7 \pm 0.22$ & 0.24 & 3.9 \\
& & & & 0.015
\end{tabular}

Well diameter: $6.0 \mathrm{~mm}$........ (100 $\mu \mathrm{l}$ was tested), Sample concentration $(20 \mathrm{mg} / \mathrm{ml})$, NA: No activity, data are expressed in the form of mean \pm Standard deviation.

\section{ACKNOWLEDGMENT}

Very thanks due to Dr Ahmed Metwally and Dr Ahmed Ez, PhD, Pharmacognosy Department, Faculty of Pharmacy, Al-Azhar University for mass and NMR facilities.

\section{REFERENCES}

Agrawal, P. K. (1989): “Carbon-13 NMR of Flavonoids” Elsevier Oxford, New York, pp. 96116.

Al-Ali, K. H., El-Beshbishy, H. A., Alghaithy, A. A., Abdallah, H., El-Badry, A. A. and Abdel-Sattar, E. (2013): "In vitro antioxidant potential and antiprotozoal activity of methanolic extract of Mentha longifolia and Origanum syriacum" J. Biological Sciences 13(4), 207-216. 
Areias, F. M., Valentao, P., Andrade, P. B., Ferreres, F., and Seabra, R. M. (2001): "Phenolic fingerprint of peppermint leaves" Food Chem. 73(3), 307-311.

Asekun, O. T., Grierson, D. S., and Afolayan, A. J. (2007): "Effects of drying methods on the quality and quantity of the essential oil of Mentha longifolia L. subsp. Capensis" Food Chem. 101 (3), 995-998.

Bhat, S., Maheshwari, P., Kumar, S., Kumar, A. (2002): "Mentha species: in vitro regeneration and genetic transformation" Mol Biol Today 3(1), 11-23.

Baris, O., Karadayi, M., Yanmis, D., Guvenalp, Z., Bal, T. and Gulluce, M. (2011): "Isolation of 3 flavonoids from Mentha longifolia (L.) Hudson subsp. longifolia and determination of their genotoxic potentials by using the E. coli WP2 test system" Journal of Food Science 76 (9), 212-217.

Baruah, P., Barua, N. C., Sharma, R. P., Baruah, J. N., Kulanthaivel, P., Herz, W. (1984): "Flavonoids from Millettia pulchra" Phytochemistry 23, 443-447.

Bauer, A. W., Kirby, W. M. M., Sheriss, J. C., Turck, M. (1966): “Antibiotic susceptibility testing by standardized single method" American Journal of Clinical Pathology 45, 493-496.

Eli, A Y., Yili, A., Liu, Y. and Aisa, H. A. (2012): "Chemical constituents of Mentha longifolia from Xinjiang" Chemistry of Natural Compounds 48(4), 683-684.

Ferreira, M. A., Moir, M., Thomson, R. H. (1974): "New pterocarpenes from Brya ebenus" J. C. S Perkin 1, 2429-2435.

Gangadevi, V. and Muthumary, J. (2007): "Preliminary studies on cytotoxic effect of fungal taxol on cancer cell lines" African J. of Biotechnol. 6, 1382-1386.

Gohari, A. R., Saeidnia, S., Shahverdi, A. R., Yassa, N., Malmir, M., Mollazade, K. and Ali Reza Naghinejad, A. R. (2009): "Phytochemistry and antimicrobial compounds of Hymenocrater calycinus" EurAsia J BioSci 3, 64-68.

Gorin, P. A. J. and Mazurek, M. (1975): "Further studies on the assignment of signals in ${ }^{13} \mathrm{C}$ magnetic resonance spectra of aldoses and derived methyl glycosides" Can. J. Chem., $53,1212-1223$.

Gulluce, M., Sahin, F., Sokmen, M., Ozer, H., Daferera, D., Sokmen, A. (2007): "Antimicrobial and antioxidant properties of the essential oils and methanol extract from Mentha longifolia L. ssp. Longifolia" Food Chememisty 103, 1449-1456.

Harborne, J. B. (1994): "The Flavonoids, Advances in research since 1986" Chapman and Hall, London, New York, 116-238, 446-471.

He, J., Chen, L., Heber, D., Shi, W., Lu, Q. Y. (2006): "Antibacterial compounds from Glycyrrhiza uralensis" J. Nat. Prod. 69, 121-124.

Khan, F. A., Khan, A., Hussain, J., Khattak, M., Shah, S. M. and Hassan, M. (2011): "Assessment of antioxidant and antibacterial activities of Mentha longifolia" Journal of Pharmacy Research 4(7), 2338-2339.

Lee, J. H., Ku, C. H., Baek, N., Kim, S. H. Park, H. W. and Kim, D. K. (2004): "Phytochemical Constituents from Diodia teres" Arch Pharm Res 27(1), 40-43. 
Malikova, V. M. and Yuldashev, M. P. (2002): "Phenolic compounds of plants of the Scutellaria L. genus. Distribution, structure and properties" Chemistry of natural compounds 38(4), 396.

Markham, K. R. (1982): "Techniques of Flavonoid Identification" Academic Press Inc., London, 36-49.

Markham, K. R., Ternai, B., Stanley, R., Geiger, H. and Mabry, T. J. (1978): "Carbon-13 NMR studies of flavonoids-III" Tetrahedron, 34, 1389-1397.

Mimica-Dukić, N., Popović1, M., Jakovljević, V., Szabo, A. and Gašić, O. (1999): "Pharmacological studies of Mentha longifolia phenolic extracts. II. Hepatoprotective activity" Pharmaceutical Biology 37(3), 221-224.

Miyase, T., Sano, M., Nakai, H., Muraoka, M., Nakazawa, M., Suzuki, M., Yoshino, K., Nishihara, Y., Tanai, J. (1999): "Antioxidants from Lespedeza homoloba" Phytochemistry 52, 303-310.

Mosmann, T. (1983): "Rapid colorimetric assay for cellular growth and survival: application to proliferation and cytotoxicity assays" J. Immunol. Methods 65, 55-63.

Okoh, O., Afolayan, A. (2011): "The effects of hydrodistillation and solvent free microwave extraction methods on the chemical composition and toxicity of essential oils from the leaves of Mentha longifolia L. subsp. capensis” African. J Pharm Pharmacol 5(22), 2474-2478.

Raj, X. J., Bajpai, P. K., Kumar, G. P., Murugan, M. P., Kumar, J., Chaurasia, O. P. and Bala, S. S. (2010): "Determination of total phenols, free radical scavenging and antibacterial activities of Mentha longifolia Linn. Hudson from the Cold Desert, Ladakh, India" Phcog J 2(12), 470-475.

Satake, T., Kamiya, K., Saiki, Y., Hama, T., Fujimoto, Y., Kitanaka, S., Kimura, Y., Uzawa, J., Endang, H., and Umar, M. (1999): "Studies on the constituents of fruits of Helicteres isora L." Chem Pharm Bull 47, 1444-1447.

Shabana, M. H. Hashem, F. A. M., Singab, A., Khaled, S. and Farrag. (2013): "Protective and therapeutic activities of Mayodendron igneum Kurz against paracetamol induced liver toxicity in rats and its bioactive constituents" Journal of Applied Pharmaceutical Science 3 (7), 147-155.

Tanaka, H., Oh-Uchi, T., Etoh, H., Shimizu, H., Tateishi, Y. (2002): "Isoflavonoids from the roots of Erythrina poeppigiana" Phytochemistry 60, 789-794.

Ternai, B. and Markham, K. R. (1976): "Carbon-13 NMR studies of flavonoids-I flavones and flavonols" Tetrahedron 32, 565-569.

Tommasi, DeN., Simone, DeF., Pizza, C., Mahmood, N., Moore, P., Cinzia, C., Orsi, N. (1992): "Constituents of Eriobotrya Japonica. A study of their antiviral properties" J Nat Prod 55, 1067-73.

Voirin, B., Bayet, C., Faure, O., and Jullien, F. (1999): "Free flavonoid aglycones as markers of parentage in Mentha aquatica, M. citrata, M. spicata and M. x piperita" Phytochemistry 50 (7), 1189-1193. 
Wagner, H., Chari, V. M. and Sonnenbichler, J. (1976): “13 C-NMR-spektren naturlich vorkommender flavonoide" Tetrahedron Letters 21, 1799-1802.

Yen, G. C. and Duh, P. D. (1994): "Scavenging effect of methanolic extracts of peanut hulls on free radical and active oxygen species" J. Agric. Food Chem. 42, 629-632.

$$
\begin{aligned}
& \text { مواد فينولية والفاعلية الحيوية لعثب منثا لونجيفوليا }
\end{aligned}
$$

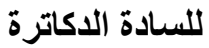

$$
\begin{aligned}
& \text { (1) حمح حسنى (2) ايهاب عبدالو هاب رجب (3) محم فوزى عبدالو هاب (4) حمدون عبدالحمبد محم } \\
& \text { مســـن } \\
& \text { قسم العقاقير بكلية الصيدلة جامعة الازهر القاهرة مصر }
\end{aligned}
$$

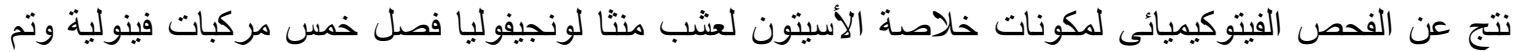

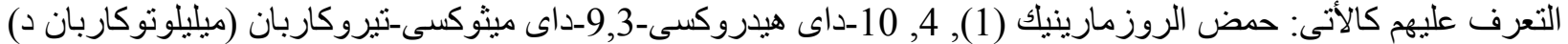

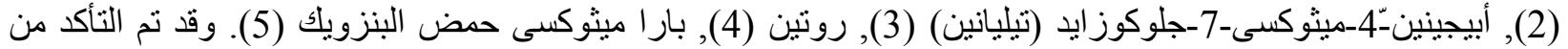

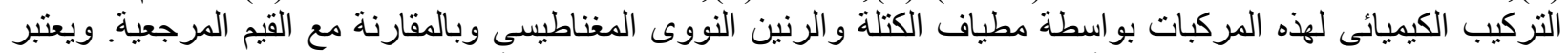

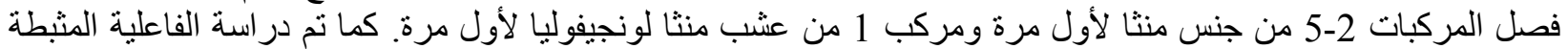

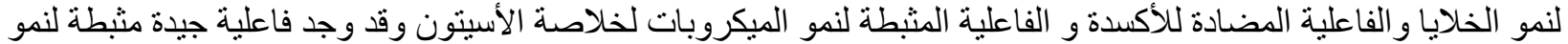
بعض الخلاياو فاعلية جيدة مثبطة لنمو معظم الميكروبات. وتم ملاحظة ان لخلاصة الأسيتون تأثير ضعيف كمضادة للأكسدة . 